\title{
A cross sectional observational study to evaluate various cutaneous manifestations in geriatric age group
}

\author{
Talukdar $\mathrm{K}^{1}$, Mitra $\mathbf{D}^{2}$ \\ ${ }^{1}$ Dr. Krishna Talukdar, Associate Professor \& Incharge HOD, Jorhat Medical College, Jorhat, Assam, ${ }^{2}$ Dr. Debdeep \\ Mitra, Graded Specialist, Air Force Hospital Jorhat, Assam, India.
}

Address for Correspondence: Dr. Krishna Talukdar, Email: drkrishna.talukdar@gmail.com

\begin{abstract}
Introduction: With an improvement in medical services and with increased life expectancy, in both developed and developing nations, the geriatric population is increasing and with this their medical needs including their cutaneous problems are also gaining more attention. This study highlights the various dermatoses prevalent in the geriatric population. Early detection of few of the dermatoses not only helps in their early treatment but also prevents further progression. Skin being the mirror of the internal body system often gives definitive clues for diagnosing several systemic ailments which are quite common in this age group. On the other hand skin is also at the receiving end and many systemic illnesses and medications modify the dermatological presentation in the elderly population. Methods: The geriatric patients (aged 60 years and above), attending Dermatology Out-patient Department in a tertiary hospital over a period of one year were included in this study. About 360 patients were included in this study. Results: Itching was the commonest presenting complaint and wrinkles were the commonest dermatological finding. Disorders of hair and nails was also were very common. A total of 7 patients out of the study group had malignant skin cancers and they were managed and followed up after the end of the study period to note any recurrence. Conclusion: The 60 and older patient population is a rapidly growing dermatology clientele with unique skin, hair, and nail issues. This study highlights the various dermatoses peculiar to the geriatric population and aims at sensitizing the fraternity to the specific needs of this special age group.
\end{abstract}

Key words: Geriatric, Skin cancers, Photo-ageing.

\section{Introduction}

Aging is a "biological reality, which has its own dynamic, beyond human control [1]. Geriatrics is a Greek word, where Gerus means 'old age' and iatrike means 'medical treatment'. It is the branch of medicine concerned with the problems of ageing. In both developed and developing nations, the geriatric population is increasing [2]. The geriatric population ( $>$ 60years) in India was $6.9 \%$ of total population in 2011 AD (Family Welfare Statistics in India-2014) and will contribute $12.4 \%$ of total population by $2026 \mathrm{AD}$. This is due to better medical facility, better socio-economic condition and increased awareness of their health. The consciousness of the geriatric people as well about their physical fitness also made them concern of their skin problem. Therefore, geriatric patients with different skin manifestations attending out-patient department have increased.

Manuscript received: $18^{\text {th }}$ Jan 2016

Reviewed: $28^{\text {th }}$ Jan 2016

Author Corrected: $08^{\text {th }} \mathrm{Feb} 2016$

Accepted for Publication: $17^{\text {th }}$ Feb 2016
Geriatric people are prone to develop some of the systemic diseases like diabetes mellitus, hypertension, anaemia, cardiovascular disorder, vascular insufficiency, etc. which may lead to different cutaneous manifestations in this age group. The dermatological disorders in old age are not only due to physical consequences of ageing but also due to effect of prolonged environmental exposure, especially ultraviolet radiation [3]. Social and psychological factors also can influence skin changes in old age. Studies on the cutaneous manifestations in geriatric age group both in India and abroad are still lacking. The growing health concern of geriatric population for their skin problems leading to increase in their outdoor attendance influenced us to take up the present study. The study includes incidence and clinical pattern of cutaneous manifestations along with the associated systemic diseases in geriatric age group. 


\section{Material and Methods}

The geriatric patients (aged 60 years and above), attending Dermatology Out-patient Department in a tertiary hospital of North East India, during the period of one year were included in this study.

A detailed history of the patient including the duration, evolution of the disease and other relevant histories were taken. A thorough clinical examination including general physical, systemic and cutaneous examinations were done in all the patients. Routine examination of blood, urine, stool and blood sugar were carried out in all the patients. Special investigations like Liver Function Tests, Renal Function Tests, Tzanck test, Gram stain, Culture and Sensitivity, KOH preparation, Slit skin smear for Acid Fast Bacilli, Histopathological examination, Immunofluorescence test, ECG and radiological investigations like Chest X-ray and other relevant investigations were done wherever required. The relevant cutaneous findings in all the patients were recorded.

Observations: Sixteen thousand eight hundred and sixty four patients attended Dermatology Out-patient Department, during the study period. Among them 360 were of geriatric age group with cutaneous manifestations. So the total incidence of Geriatric dermatoses was about $2.1 \%$. There was a noted male preponderance noted in the study with about $257(71.4 \%)$ male patients and $103(28.6 \%)$ female patients.

Table 1: Specific disorders due to senility

\begin{tabular}{|l|l|l|l|}
\hline $\begin{array}{l}\text { Total Number of } \\
\text { Patients }\end{array}$ & Disorders due to senility & Number of patients & $\begin{array}{l}\text { Percentage } \\
\mathbf{( \% )}\end{array}$ \\
\hline \multirow{5}{*}{360} & Wrinkles Guttate & 308 & 85.6 \\
\cline { 2 - 4 } & $\begin{array}{l}\text { Idiopathic } \\
\text { Hypomelanosis }\end{array}$ & 21 & 22.5 \\
\cline { 2 - 4 } & Senile Lentigines & 39 & 10.8 \\
\cline { 2 - 4 } & Senile Xerosis & 34 & 9.4 \\
\cline { 2 - 4 } & Senile Purpura Racouchot & 28 & 7.8 \\
\cline { 2 - 4 } & $\begin{array}{l}\text { Favre } \\
\text { Syndrome }\end{array}$ & 3.3 \\
\cline { 2 - 4 } & Stellate Scars & 12 & 3.3 \\
\cline { 2 - 3 } & Senile Pruritus & 12 & 3.3 \\
\hline
\end{tabular}

Table 2: Benign, pre-malignant and malignant neoplasm

\begin{tabular}{|c|c|c|c|c|}
\hline $\begin{array}{l}\text { Total number } \\
\text { of patients }\end{array}$ & \multicolumn{2}{|l|}{ Neoplasm } & $\begin{array}{l}\text { Number of } \\
\text { patients }\end{array}$ & $\begin{array}{l}\text { Percentage } \\
(\%)\end{array}$ \\
\hline \multirow{8}{*}{360} & \multirow{3}{*}{ Benign } & Cherry Angioma & 210 & 58.3 \\
\hline & & Seborrhoeic Keratosis & 84 & 23.3 \\
\hline & & Skin Tag & 74 & 20.6 \\
\hline & $\begin{array}{l}\text { Pre- } \\
\text { malignant }\end{array}$ & Actinic Keratosis & 4 & 1.1 \\
\hline & \multirow{4}{*}{ Malignant } & $\begin{array}{ll}\text { Squamous } & \text { Cell } \\
\text { Carcinoma } & \end{array}$ & 3 & 0.8 \\
\hline & & Basal Cell Carcinoma & 2 & 0.6 \\
\hline & & Malignant Melanoma & 1 & 0.3 \\
\hline & & Erythroplasia of Queyrat & 1 & 0.3 \\
\hline
\end{tabular}


Table 3: Eczematous conditions

\begin{tabular}{|c|c|c|c|}
\hline $\begin{array}{l}\text { Total number of } \\
\text { patients }\end{array}$ & $\begin{array}{l}\text { Eczematous } \\
\text { Conditions }\end{array}$ & Number of patients & $\begin{array}{l}\text { Percentage } \\
(\%)\end{array}$ \\
\hline \multirow{10}{*}{360} & $\begin{array}{ll}\text { Lichen } & \text { Simplex } \\
\text { Chronicus } & \end{array}$ & 31 & 8.6 \\
\hline & Seborrhoeic Dermatitis & 16 & 4.4 \\
\hline & Gravitational Eczema & 15 & 4.2 \\
\hline & Nummular Eczema & 12 & 3.3 \\
\hline & Asteatotic Eczema & 8 & 2.2 \\
\hline & Pompholyx & 5 & 1.4 \\
\hline & Atopic Dermatitis & 3 & 0.8 \\
\hline & $\begin{array}{l}\text { Polymorphic Light } \\
\text { Eruption }\end{array}$ & 14 & 3.9 \\
\hline & Contact Dermatitis & 14 & 3.9 \\
\hline & $\begin{array}{ll}\text { Airbone } & \text { Contact } \\
\text { Dermatitis } & \end{array}$ & 6 & 1.7 \\
\hline
\end{tabular}

Dermatophyte infections were noted in about $61(16.9 \%)$ of the study group and the incidence of the other infection and infestations is documented in Table 4.

Table 4: Infection and infestation

\begin{tabular}{|c|c|c|c|c|c|}
\hline \multirow{2}{*}{\multicolumn{2}{|c|}{ Infection and Infestation }} & \multicolumn{2}{|c|}{ Number } & \multicolumn{2}{|c|}{ Total Number } \\
\hline & & \multirow{2}{*}{\begin{tabular}{|l|} 
No. \\
27
\end{tabular}} & \multirow{2}{*}{\begin{tabular}{|l|}
$\mathbf{( \% )}$ \\
7.5 \\
\end{tabular}} & \multirow[t]{2}{*}{ No. } & $(\%)$ \\
\hline \multirow{7}{*}{ Fungal Infections } & Tinea Corporis & & & & \multirow{7}{*}{16.9} \\
\hline & Tinea Pedis & 15 & 4.2 & \multirow{6}{*}{61} & \\
\hline & Tinea Cruris & 14 & 3.9 & & \\
\hline & Tinea Faciei & 2 & 0.5 & & \\
\hline & Tinea Manuum & 3 & 0.8 & & \\
\hline & Candidiasis & 12 & 3.3 & & \\
\hline & P. Versicolor & 7 & 1.9 & & \\
\hline \multirow{9}{*}{ Bacterial Infections } & Furuncle & 5 & 1.4 & \multirow{9}{*}{32} & \multirow{9}{*}{8.9} \\
\hline & Carbuncle & 1 & 0.3 & & \\
\hline & Folliculitis & 4 & 1.1 & & \\
\hline & Ecthyma & 4 & 1.1 & & \\
\hline & Cellulitis & 4 & 1.1 & & \\
\hline & Impetigo & 2 & 0.5 & & \\
\hline & Erysipelas & 1 & 0.3 & & \\
\hline & Leprosy & 9 & 2.5 & & \\
\hline & Lupus Vulgaris & 2 & 0.5 & & \\
\hline \multirow{4}{*}{ Viral Infections } & Herpes Zoster & 11 & 3.1 & \multirow{4}{*}{28} & \multirow{4}{*}{7.8} \\
\hline & Post Herpetic Neuralgia & 7 & 1.9 & & \\
\hline & Herpes Simplex & 3 & 0.8 & & \\
\hline & Viral Wart & 7 & 1.9 & & \\
\hline Parasitic Infestation & Scabies & 16 & 4.4 & 16 & 4.4 \\
\hline
\end{tabular}


The relative incidence of the other dermatoses is grouped under miscellaneous conditions and is as per Table No 5 .

Table 5: Miscellaneous dermatoses

\begin{tabular}{|l|l|l|l|l|}
\hline \multirow{2}{*}{$\begin{array}{l}\text { Miscellaneous } \\
\text { Dermatoses }\end{array}$} & Number & $\mathbf{( \% )}$ & Total Number \\
\cline { 2 - 5 } $\begin{array}{l}\text { Papulosquamous } \\
\text { Disorders: }\end{array}$ & & & No. & $\mathbf{( \% )}$ \\
\hline - Psoriasis & 15 & 4.2 & 7.8 \\
\hline - Lichen Planus & 13 & 3.6 & & \\
\hline Urticaria & & & 17 & 4.7 \\
\hline Vitiligo & & & 11 & 3.1 \\
\hline Erythroderma & & & 11 & 3.1 \\
\hline Bullous Disorders: & & & 10 & 2.8 \\
\hline - Bullous Pemphigoid & 8 & 2.2 & & \\
\hline - Pemphigus Vulgaris & 2 & 0.6 & & 2.8 \\
\hline Prurigo Nodularis & & & 10 & 2.2 \\
\hline Ulcers: & & & 8 & \\
\hline - Trophic Ulcer & 4 & 1.1 & & 1.1 \\
\hline - Stasis Ulcer & 3 & 0.8 & & 0.8 \\
\hline - Pressure Ulcer & 1 & 0.3 & & 0.6 \\
\hline Drug Reaction & & & 5 & \\
\hline $\begin{array}{l}\text { Discoid } \\
\text { Erythematosus }\end{array}$ & & & 4 & \\
\hline $\begin{array}{l}\text { Xanthelasma } \\
\text { Palpebrarum }\end{array}$ & & & 4 & 1.1 \\
\hline Delusion of Parasitosis & & & 3 & \\
\hline Pellagra & & & & \\
\hline Necrobiosis Lipoidica & & & & \\
\hline
\end{tabular}

Pruritus was noted in about $296(82.2 \%)$ of the patients who sought consultation in our study group. This was the most common presenting complaint and the various causes of pruritus are shown in Table 6.

Table 6: Incidence of various causes of pruritus

\begin{tabular}{|l|l|l|}
\hline Various causes of pruritus & Number of patients & $\begin{array}{l}\text { Percentage } \\
(\mathbf{\%})\end{array}$ \\
\hline Dermatoses & 283 & 78.6 \\
\hline Senile Pruritus & 12 & 3.3 \\
\hline Systemic Disorder: & & \\
\hline Diabetes Mellitus & 1 & 0.3 \\
\hline Total & $\mathbf{2 9 6}$ & $\mathbf{8 2 . 2}$ \\
\hline
\end{tabular}

Table No 2 highlights the various benign, pre-malignant and malignant cutaneous findings in this study. As this age group is particularly vulnerable to various tumours, this study focused on the premature detection of the various malignant conditionsTable No 2 highlights the various benign, pre-malignant and malignant cutaneous findings in this study. As this age group is particularly vulnerable to various tumours, this study focused on the premature detection of the various malignant conditionsAbout one third of the study population had one or the other form of eczema and Table No 3 classifies the various eczemas the patient's had. About $60 \%$ of the study population was in the age group of 60 to 
65 years. 66 to 70 years age group bracket comprised about $20 \%$ of the study population and as the age group increased the number of patients gradually decreased. The various dermatoses and their relative incidence are noted as per Table-1.

Our study tried to link the various systemic conditions common in this geriatric population and the dermatological manifestations. The systemic findings found to be associated with the various dermatoses are shown in table 7 .

Table 7: Systemic findings associated with cutaneous manifestations

\begin{tabular}{|l|l|l|l|l|l|l|l|l|l|l|l|}
\hline $\begin{array}{l}\text { Systemic } \\
\text { diseases }\end{array}$ & \multicolumn{2}{l}{$\begin{array}{l}\text { Patients } \\
\text { Total }\end{array}$} & Infection & \multicolumn{2}{l|}{ Eczema } & \multicolumn{2}{l|}{$\begin{array}{l}\text { Neoplasm } \\
\text { Malignancy) }\end{array}$} & \multicolumn{2}{l|}{ Miscellaneous } \\
\cline { 2 - 12 } & No. & $(\%)$ & No. & $(\%)$ & No. & $(\%)$ & No. & $(\%)$ & No. & $(\%)$ \\
\hline $\begin{array}{l}\text { Diabetes } \\
\text { Mellitus }\end{array}$ & 39 & 10.8 & 29 & 8.1 & 4 & 1.1 & 0 & 0.0 & 8 & 2.2 \\
\hline Anaemia & 23 & 6.4 & 7 & 1.9 & 4 & 1.1 & 5 & 1.4 & 13 & 3.6 \\
\hline Hypertension & 18 & 5 & 2 & 0.6 & 4 & 1.1 & 0 & 0.0 & 13 & 3.6 \\
\hline $\begin{array}{l}\text { Respiratory } \\
\text { Disease }\end{array}$ & 2 & 0.6 & 1 & 0.3 & 1 & 0.3 & 0 & 0.0 & 0 & 0.0 \\
\hline $\begin{array}{l}\text { Rheumatoid } \\
\text { Arthritis }\end{array}$ & 1 & 0.3 & 0 & 0.0 & 0 & 0.0 & 0 & 0.0 & 1 & 0.3 \\
\hline
\end{tabular}

\section{Discussion}

There are two basic theories of ageing [4] - the Programmatic Theory which views ageing as an ordered process delicately programmed by the gene and the Stochastic theory which suggests that the ageing is caused by the progressive retention and amplification of errors in the replication of genetic information in the somatic cells because of oxidative stress. However, ageing occurs as a result of interaction between genetic programme and cumulative wear and tear during the life span. Cutaneous ageing includes intrinsic changes which are inevitably attributable to the passage of time alone, and changes resulting from environmental factors e.g $90 \%$ age associated cosmetic problems are caused by ultraviolet radiation [5]. The intrinsic changes fall into two categories, those that appear to originate within the tissue themselves like greying of hair and those that result from senile changes in other organs like atrophy of sebaceous gland as a result of reduction of androgen secretion [6].

Epidermal changes with ageing: The cell turnover rate is halved between the third and seventh decade of life [7] resulting in impaired wound healing. In elderly, there is change in the nature of corneocyte and age associated decrease in the content of epidermal filaggrin [8]. The skin becomes dry, flaky and sometimes itchy especially that of lower legs. associated decrease in the content of epidermal filaggrin [8]. The skin becomes dry, flaky and sometimes itchy especially that of lower legs.
There is decrease in the number of enzymatically active melanocyte per unit surface area of skin and $20-50 \%$ reduction in number of morphologically identifiable epidermal Langerhan's cell. The permeability of the skin also changes with age making it more permeable to chemical substances. Ageing markedly delays the recovery of barrier function of epidermis due to decreased amount of lipids in the newly formed lamellar bodies [9].

The most striking and consistent histologic change is flattening of the dermal-epidermal junction with effacement of both the dermal papillae and epidermal rete pegs [10]. As dermal-epidermal separation occurs more readily in old skin there is tendency of the elderly to torn skin and superficial abrasion following minor trauma.

Dermal changes with ageing: The wrinkling of old skin is almost entirely the result of changes in the dermis. The dermis diminishes in bulk and in absolute terms the collagen per unit area of unexposed skin decreases with age [11]. With age, the collagen bundles become fragmented and disoriented, and elastin fibres become progressively reduced [2]. There is steady decrease in the number and size of mast cells and fibroblasts [3]. The deep expression lines seem to result from contractions of connective tissue septa within the subcutaneous fat. The elastic fibres often appear fragmented with small cysts and lacunae especially in the dermal-epidermal junction. Over the age of 70 
years, there is loss of collagens I and III in the papillary dermis with an associated increase in matrix metalloproteinase. Reactive oxygen species and free radicals are agents causing degeneration in aged skin.

Changes in cutaneous glands: [7]: There is reduction in the number of eccrine glands and of the output per gland in old age. Sebaceous gland size and number does not appear to change with age though the sebum production is reduced as a result of concomitant decrease in production of gonadal or adrenal androgens. Apocrine gland size and function also decreases with ageing. Lipofuscin 'age pigment' gradually accumulates with age in the secretory cells of both eccrine and apocrine glands.

Hair changes in ageing: [8]: Greying of hair usually becomes evident almost in everyone around age 50 years. It occurs as a result of total loss of melanocyte from hair bulb as well as deficiency in tyrosinase enzyme The density of hair follicles of scalp steadily decreases with age, more rapidly in bald than in nonbald persons. It results from shortening of duration of anagen and gradual rise of follicles in telogen.

Photoageing: [6]: Photoageing occurs not only in fairskinned individuals (skin types I and II) but also in individuals with darker skin (types III and IV) with a history of ample past sun exposure. It usually involves exposed skin most severely. UVB photons are on average 100 times more energetic than UVA photons and are responsible for sunburn, sun tanning and photocarcinogenesis following sun exposure. UVA can produce elastosis when given in higher doses. In photoageing, the epidermis becomes thickened showing acanthosis, cellular atypia, loss of polarity, irregularities of cell size and staining properties.

In actinically damaged skin, the glycosaminoglycans and proteoglycans comprising the ground substance are greatly increased whereas the amount of collagen decreases. Elastosis, an overgrowth of abnormal elastic fibres, is a prototypical feature of actinically damaged skin. It is characterized histologically by tangled masses of degraded elastic fibres that further deteriorate to form an amorphous mass. The 60 and older patient population is a rapidly growing dermatology clientele with unique skin, hair, and nail issues. Skin barrier is a significant issue creating the backdrop for conditions, such as xerosis, pruritus, and purpura.
Our study highlighted the relative incidence of the physiological and pathological conditions with which the elderly population presents. More than $80 \%$ of the elderly population had different grades of wrinkles and 7 out of the 360 patients enrolled for the study had some form of a cutaneous malignant condition. Early detection and treatment of pre-malignant and malignant conditions was one of the major achievements of this study. Various eczematous conditions were common in this age group due to deficient barrier function of skin and the study tried to classify the various types of eczemas. Priritus was a common presenting complaint noted in this geriatric population and the various causes of pruritus were looked into and an attempt was made to treat the underlying cause.

\section{Conclusion}

The geriatric patients usually develop wide variety of physiological and pathological cutaneous changes. In most of the occasions, sunlight is the precipitating factor. Some of the disorders like photoageing, senile lentigines, idiopathic guttate hypomelanosis and premalignant conditions can be prevented or minimized by proper education about photo-protection and health care. Early detection and proper management of cutaneous malignancy is crucial to prevent local tissue destruction and metastasis. The high incidence of systemic disorders in association with cutaneous manifestations stresses the importance of evaluation and screening of the geriatric patients clinically as well as with investigative procedures for better management.

Emerging science suggests that photodamage and possibly even non melanotic skin cancers may be ameliorated with laser- and light-based technology. Hair disorders and alopecia may be associated with underlying comorbidities of an endocrine and cardiovascular nature. Skin cancer treatment modalities are becoming less invasive with new topical pharmacotherapeutics to treat early malignancies.

\section{Funding: Nil,}

Conflict of interest: None.

Permission of IRB: Yes

\section{References}

1. World Health Organization. Definition of an older or elderly person. Available from www.who.int/healthinfo/survey/ageingdefinitiono lder/en/index.html. 
2. Masoro EJ. Ageing: Current Concepts in Ageing. Edited by Masoro EJ, Oxford, England, Oxford University Press, 1995, p. 3.

3. Durai PC, Thappa DM, Kumari R, Malathi M. Aging in elderly: chronological versus photoaging. Indian J Dermatol. 2012 Sep;57(5):343-52. doi: 10.4103/00195154.100473 .

4. Cerimele D, Celleno L, Serri F. Physiological changes in ageing skin. $\mathrm{Br} \mathrm{J}$ Dermatol. 1990 Apr;122 Suppl 35:13-20.

5. Farage MA, Miller KW, Berardesca E, Maibach HI. Clinical implications of aging skin: cutaneous disorders in the elderly. Am J Clin Dermatol. 2009;10(2):73-86. doi: 10.2165/00128071-200910020-00001.

6. Roberts WE. Generational dermatology: model

of prevention and multi-decade approach to the evolving aging patient. $J$ Drugs Dermatol. 2013;12(12):1396-1397.
7. Rubegni P, Poggiali S, Nami N, Rubegni M, Fimiani M. Skin diseases in geriatric patients: our experience from a public skin outpatient clinic in Siena. G Ital Dermatol Venereol. 2012 Dec;147(6):631-6.

8. Lewis DA, Travers JB, Spandau DF. A new paradigm for the role of aging in the development of skin cancer. J Invest Dermatol. 2009 Mar;129(3):787-91. doi: 10.1038/jid.2008.293. Epub 2008 Sep 25.

9. S. W. Chan. Prevalence of skin problems in elderly homes residents in Hong Kong. Hong Kong Journal of Dermatology and Venereology, vol. 14, no. 2, pp. 66-70, 2006.

10. H. Cvitanović, E. Knežević, I. Kuljanac, and E. Jančić. Skin disease in a geriatric patients group in outpatient dermatologic clinic Karlovac, Croatia. Collegium Antropologicum, vol. 34, no. 2, pp. 247-251, 2010.

11. Beauregard S, Gilchrest BA. A survey of skin problems and skin care regimens in the elderly. Arch Dermatol. 1987;123:1638-43.

\section{How to cite this article?}

Talukdar K, Mitra D. A cross sectional observational study to evaluate various cutaneous manifestations in geriatric age group .Int J Med Res Rev 2016;4(2):186-192. doi: 10.17511/ijmrr.2016.i02.011. 